\title{
Notes on Occurrence of Fruticose Lichens in Joram Top, Ziro Valley, Arunachal Pradesh with 10 New Records to the State
}

\author{
Kiran Rana ${ }^{1}$, Sanjeeva Nayaka ${ }^{2}$, Preeti Shukla ${ }^{3}$, Dalip Kumar Upreti ${ }^{4}$ \\ ${ }^{1}$ Post Graduate Government College for Girls, Sector - 42 , Chandigarh-160036, India \\ ${ }^{2}$ Lichenology and Algology Laboratory, CSIR-National Botanical Research Institute, Rana Pratap Marg, Lucknow-226001, India \\ ${ }^{3}$ Lichenology Laboratory, CSIR-National Botanical Research Institute, Rana Pratap Marg, Lucknow-226001, India \\ ${ }^{4}$ Lichenology Laboratory, CSIR-National Botanical Research Institute, Rana Pratap Marg, Lucknow-226001, India
}

\begin{abstract}
The paper enumerates 22 fruticose lichens species collected from 'Joram Top', a small village in Ziro Valley of Arunachal Pradesh. The lichen taxa belong to four genera; Cladonia (7 spp.), Ramalina (5 spp.), Teloschistes (1 sp.) and Usnea (9 spp.). The species of Usnea and Ramalina were most common in the area and found growing as epiphytes over tree trunks and twigs, whereas species of Cladonia were found growing over soil and rocks in moist places. Teloschistes found to be a rare lichen in the area was growing intermingled with Usnea and Ramalina. The study also resulted in 10 species as new records to the lichen flora of Arunachal Pradesh-Cladonia subradiata, C. subulata, C. verticillata, Ramalina hossei, R. pollinaria, Teloschistes flavicans, Usnea eumitrioides, $U$. lucea, $U$. luridorufa, and $U$. spinosula. The lichens are considered as indicators of air pollution. The luxuriant growth of fruticose lichens clearly indicates that Joram Top area is still free from air pollution.
\end{abstract}

Keywords: Lichenized fungi, cryptogam, biodiversity, North East India, Parmeliaceae.

\section{Introduction}

Lichens are composite, symbiotic organisms made up of an alga (or cyanobacteria) and a fungus. They are ubiquitously distributed and an important component of the biodiversity [1]. Lichen are of great economic importance; they are used as spice, medicine, dye and perfume by man since the time immemorial [2]. The lichen extracts have shown potential biological activities such as antimicrobial, antioxidant, anticancerous, anti-inflammatory, hepato-protective, cardioprotective etc. [3]. The lichens are also sensitive to air pollution and climate change and hence they are called as bioindicators. The lichens are being utilized biomonitoring the environmental changes worldwide [4]. By their appearance the lichens can be grouped into three main growth forms : 1. crustose - where the thallus is closely attached to the substratum without leaving any free margin 2 . foliose - the thallus in this case is loosely attached at least at the margin 3. fruticose - the thallus is attached to the substratum at one point and remaining major portion is either growing erect or hanging. The fruticose lichen usually appears as small shrub or bush [5].

In the world there are about 20,000 species of lichens and India is represented by 2500 species distributed under 322 genera and 72 families. Out of the total, about $23 \%$ of the taxa are endemic to India. Within India Western Ghats and Himalayas are the hotspots of lichen diversity. Eastern Himalayas harbors a total of 1250 species, Western Ghats 1210 and Western Himalayas with 972 species. Among various states Tamil Nadu is represented by maximum number of lichens with 812 species [6]. Although India being a megadiverse country with several biodiversity hotspots and phytogeographical regions lichen wealth of the country is insufficiently explored. In comparison to other conspicuous plant groups in the natural landscape, lichens are the most overlooked. The lichens have received little scientific attention due to the difficulties in their identification and most of the earlier collections including the type specimens are preserved in different European herbaria, hence unavailable for comparison. There are several ecologically interesting habitats which need to be explored for documentation of lichens. The north-eastern part of India is one such region with huge lichen biodiversity needing to be surveyed. In the present study Ziro Valley in Arunachal Pradesh is chosen for detailed exploration.

Arunachal Pradesh has rich floristic diversity, higher incidence of rare and threatened taxa. Approximately 5000 angiosperms taxa including 600 orchids along with 400 ferns, 48 gymnosperms, an equally high number of unexplored algae, fungi, lichens and bryophytes inhabited in its diverse habitats. Presence of numerous primitive plant species and wild relatives of cultivated plants truly justifies the region to be recognized as "cradle of flowering plants". However, systematic floristic studies on lichens of Arunachal Pradesh is recently initiated. Routh et al. [7] recorded 42 lichen species from Sessa Orchid Wildlife Sanctuary in Arunachal Pradesh while Pinokiyo et al. [8] studied the diversity and distribution of lichens 10 sites within the Mehao Wildlife Sanctuary revealing 177 species, belonging to 71 genera and 35 families. Singh and Pinakiyo [9] reported four species of foliicolous lichens while Khare et al. [10] documented the occurrence of a rare lichen Ophioparma ventosa (L.) Norman, from alpine areas of Arunachal Pradesh. Rout et al. [11-12] recorded the utilization of lichens by ethnic people in

\section{Volume 4 Issue 12, December 2015}




\section{International Journal of Science and Research (IJSR) \\ ISSN (Online): 2319-7064}

Index Copernicus Value (2013): 6.14 | Impact Factor (2014): 5.611

the state. Singh and Singh [13-14] discovered Pyrgillus tibellii Kr. P. Singh and Pushpi Singh as new species, while P. cubanus Nyl. and P. javanicus (Mont. and Bosch) Nyl. as new records for India from the state. Recently, Singh et al. [15] studied the Thelotremoid Graphidaceae of Arunachal Pradesh and described Rhabdodiscus indicus Pushpi Singh \& K.P. Singh as new species while Ocellularia neopertusariiformis Hale and $O$. subgranulosa (Homchantara \& Coppins) Lumbsch \& Papong as new records from India. These studies clearly indicate that Arunachal Pradesh is an interesting site for lichen growth. At present the state is represented by more than $33 \%$ of the total Indian flora, out of which about $30 \%$ are endemic to the entire Indo-Malayan Region.

\section{Materials and Methods}

2.1 Study site: The present study is restricted to 'Joram Top', a small village near Hapoli in Ziro Valley of Arunachal Pradesh (Fig. 1). The Ziro Valley is one of the prettiest landscapes in India located in Lower Subansiri district about $167 \mathrm{~km}$ away from capital Itanagar. It has been a favourite town for World Heritage Site for a number of years now. 'Joram Top' is situated at coordinates of $27^{\circ} 31$ '55"N longitude, $93^{\circ} 47^{\prime} 39^{\prime \prime} \mathrm{E}$ latitude and altitude of $1080 \mathrm{~m}$. With its moderate climatic conditions and variable rainfall Joram Top harbours rich diversity of plants and animals. The lichens with their luxuriant growth on soil, rock and plants make one of the most obvious and eye catching vegetation in this area.

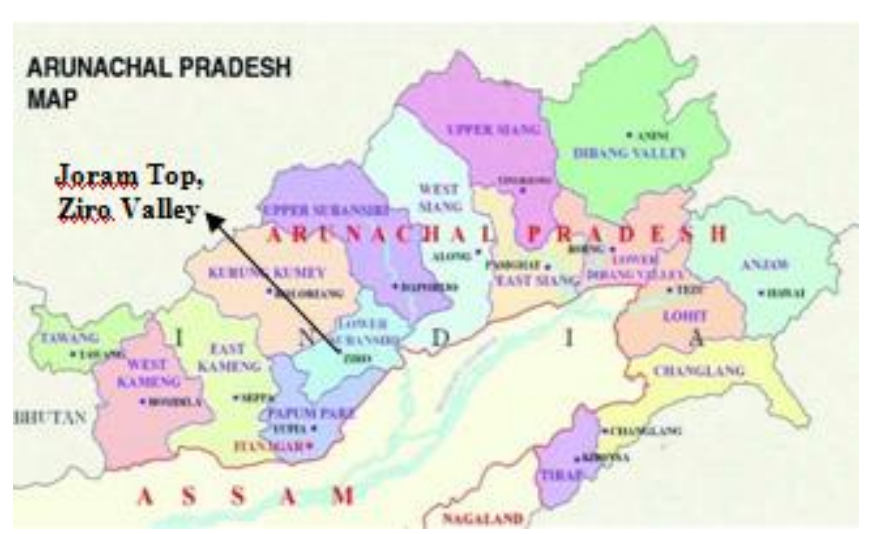

Figure 1: Map of Arunachal Pradesh showing Joram Top village in Ziro valley

\subsection{Collection, preservation and identification of lichens}

A total of 200 lichens samples were collected by one the author (KR) from the forested areas of Joram Top during the year 2008. The specimens were collected from all possible substrata such as soil, rock, shrubs, tree trunks and twigs. The specimens were segregated, dried and preserved in the herbarium of CSIR-National Botanical Research Institute, Lucknow (LWG). The lichen specimens were investigated morphologically, anatomically and chemically following recent literature [16]. The colour tests were performed with the routine reagent i.e. $\mathrm{K}$ (5\% potassium hydroxide), $\mathrm{C}$ (aqueous solution of calcium hypochloride) and $\mathrm{P}$ (paraphenylene diamine). Some lichen specimens were investigated with Thin Layer Chromatography (TLC) in solvent system A (toluene: dioxine: acetic acid) by Walker and James [17] method. The classification of Lumbusch and Huhndorf [18] followed for arranging species under various families.

\section{Result and Discussion}

The identification of lichen samples resulted in 62 species of macrolichens (foliose, fruticose and large squamulose forms). Among them fruticose lichens with 22 species make their prominent representation under four genera such as Cladonia, Ramalina, Teloschistes and Usnea (Table 1). The

Table 1: List of fruticose lichens identified from forested areas of Joram Top (New refers to Arunachal Pradesh)

\begin{tabular}{|c|c|c|c|}
\hline & Lichen species & Family & Remarks \\
\hline 1. & Cladonia cartilaginea Müll. Arg & Cladoniaceae & \\
\hline 2. & C. coniocraea (Floerke) Spreng. & Cladoniaceae & \\
\hline 3. & C. corniculata Ahti \& Kashw & Cladoniaceae & \\
\hline 4. & C. rei Schaer. & Cladoniaceae & \\
\hline 5. & C. subradiata (Vain.) Sandst. & Cladoniaceae & New \\
\hline 6. & $\begin{array}{l}\text { C. subulata (L.) Weber ex F.H. } \\
\text { Wigg. }\end{array}$ & Cladoniaceae & New \\
\hline 7. & C. verticillata (Hoffn.) Schaer. & Cladoniaceae & New \\
\hline 8. & $\begin{array}{l}\text { Ramalina cfr. himalayensis } \\
\text { Räsänen }\end{array}$ & Ramalinaceae & \\
\hline 9. & R. conduplicans Vain. & Ramalinaceae & \\
\hline 11. & R. hossei Vain. & Ramalinaceae & New \\
\hline 10. & R. pollinaria (Westr.) Ach. & Ramalinaceae & New \\
\hline 12. & R. sinensis Jatta & Ramalinaceae & \\
\hline 13. & $\begin{array}{l}\text { Teloschistes flavicans (Sw.) } \\
\text { Norm. }\end{array}$ & Teloschistaceae & New \\
\hline 14. & Usnea aciculifera Vain. & Parmeliaceae & \\
\hline 15. & U. baileyi (Stirt.) Zahlbr. & Parmeliaceae & \\
\hline 16. & U. bismolliuscula Zahlbr. & Parmeliaceae & \\
\hline 17. & U. eumitrioides Mot. & Parmeliaceae & New \\
\hline 18. & U. fragilis Stirt. & Parmeliaceae & \\
\hline 19. & U. lucea Mot. & Parmeliaceae & New \\
\hline 20. & U. luridorufa Stirt. & Parmeliaceae & New \\
\hline 21. & U. rubicunda Stirt. & Parmeliaceae & \\
\hline 22. & U. spinosula Stirt. & Parmeliaceae & New \\
\hline
\end{tabular}

genus Usnea dominated fruticose lichen community with 9 species followed by Cladonia and Ramalina with 7 and 5 species respectively. Teloschistes found to be the rare lichen in the study area is represented by only one species $T$. flavicans (Sw.) Norm. The species of Usnea and Ramalina were the most abundant lichens in the area and found growing as epiphytes over tree trunks and twigs. Some of the large species such as $U$. baileyi found hanging from twigs covered the whole tree. On the other hand species of Cladonia were found growing over soil and rocks in moist places. They almost covered the ground like carpets. It is observed that the Cladonia species grew in mixed population giving a tough challenges for collection and identification; whereas T. flavicans found growing intermingled with Usnea and Ramalina, and hence evading the sight of collectors. Therefore only one specimen could be collected.

Present study also resulted in 10 species as new records for Arunachal Pradesh. Their brief description and distribution in India are as follows;

\section{Volume 4 Issue 12, December 2015}




\section{International Journal of Science and Research (IJSR) \\ ISSN (Online): 2319-7064}

Index Copernicus Value (2013): 6.14 | Impact Factor (2014): 5.611

Cladonia subradiata (Vain.) Sandst. (Fig. 2): Primary thallus squamulose, greenish brown on upper side, white on lower side. Podetia $15-20 \mathrm{~mm}$ tall, simple to sparingly branched, corticated at base, granulose sorediate upwards, with microsquamulose, hymenial discs brown. Chemistry: P+ orange-red, fumarprotocetraric acid present. Earlier this species was known from Himachal Pradesh, Jammu and Kashmir, Sikkim and Tamil Nadu [19]. Specimens examined: On rock, 08-027027, 08-027033, 08-027034 (LWG); on soil, 08-027032 (LWG).

Cladonia subulata (L.) Weber ex F.H. Wigg. (Fig. 3): Primary thallus squamulose, grey-white to dark, persistent. Podetia greyish green to grey-brown, 10-20 $\mathrm{mm}$ tall, escyphose, sparingly branched, subulate, corticated or decorticate at base and with microsquamules, farinosesorediate upwards, hymenial discs brown. Chemistry: Podetia $\mathrm{P}+$ red, fumarprotocetraric acid present. Earlier this species was known from Jammu and Kashmir, Sikkim and Uttarakhand [19]. Specimens examined: On soil, 08027030/A (LWG).

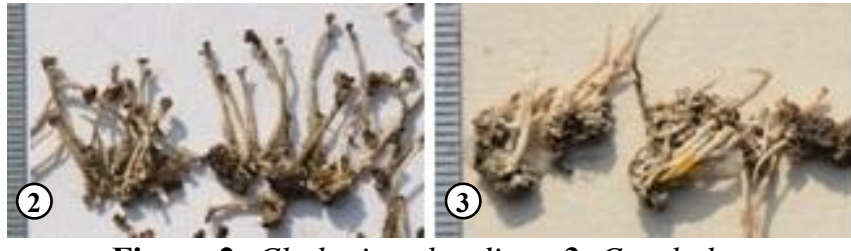

Figure 2: Cladonia subradiata, 3. C. subulata

Cladonia verticillata (Hoffn.) Schaer. (Fig. 4): Primary thallus squamulose, brown, lobed, persistent. Podetia greygreen, 15-35 $\mathrm{mm}$ tall, areolate-subcorticate, esorediate, scyphose; scyphi 3-5 mm wide, shallow, closed, squamulose, dentate, profusely proliferating from centre into many tiers of scyphi, hymenial discs brown. Chemistry: Podetia P+ red, fumarprotocetraric acid present. Earlier this species was known from Meghalaya, Sikkim and Uttarakhand [19]. Specimens examined: On rock, 08-027024 (LWG); on soil, 08-027023 (LWG).

Ramalina hossei Vain. (Fig. 5): Thallus tufted, erect, up to 4-6 $\mathrm{cm}$ tall, yellowish grey to brownish, branches up to $2 \mathrm{~mm}$ wide, nervosa, pseudocyphellate, granular sorediate, minute spinules present at the rim of soralia, chondroid tissue cracked, medulla solid. Apothecia absent. Chemistry: Usnic acid and sekikaic acid aggregate present. Earlier this species was known from Meghalaya, Uttarakhand and West Bengal hills [20]. Specimens examined: On bark, 08-027069, 08027071 (LWG)
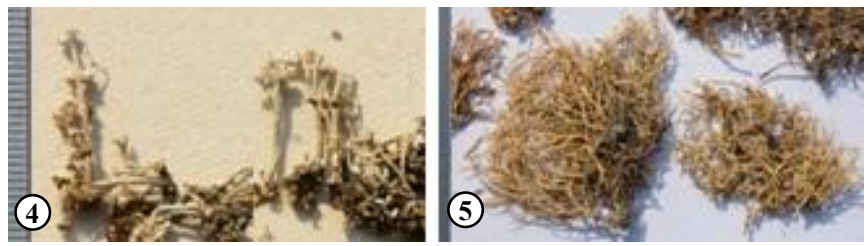

Figure 4: Cladonia verticillata, 5. Ramalina hossei

Ramalina pollinaria (Westr.) Ach. (Fig. 6): Thallus up to 4 $\mathrm{cm}$ tall, brownish, branches flattened, 5-12 mm wide, much branched at apices, granular sorediate, chondroid tissue not cracked, medulla solid. Apothecia absent. Chemistry: Usnic acid and evernic acid present. Earlier this species was known from Andhra Pradesh, Himachal Pradesh, Jammu \& Kashmir and Uttarakhand [20]. Specimens examined: On bark, 08027075, 08-027129 (LWG).

Teloschistes flavicans (Sw.) Norm. (Fig. 7): Thallus erect to pendent, irregularly branched, branches terete, up to 0.5 $0.8 \mathrm{~mm}$ thick, yellow to orange-red, smooth, white-granular sorediate, soralia orbicular to elongate, fibrils black tipped, scattered. Apothecia absent. Chemistry: Thallus K + purpleviolet, parietin present. Earlier this species was known from Karnataka, Kerala and Tamil Nadu [20]. Specimens examined: On bark, 08-027110 (LWG).
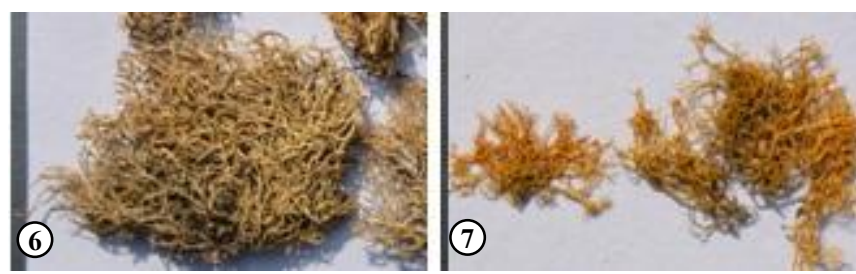

Figure 6: Ramalina pollinaria, 7. Teloschistes flavicans

Usnea eumitrioides Mot. (Fig. 8): Thallus subcaespitose, up to $5-7 \mathrm{~cm}$ tall, basally blackish, yellow brown to olivaceous brown upwards, branching dichotomous to sympodial, divergent, lateral branch-lets dense, surface branches minutely tuberculate-isidiate, isidia whitish, filiform, central axis pale. Apothecia absent. Chemistry: Medulla $\mathrm{K}+$ red, $\mathrm{P}+$ deep yellow, stictic acid complex present. Earlier this species was known from Himachal Pradesh, Nagaland, Sikkim, Tamil Nadu, Uttarakhand and West Bengal-hills [20]. Specimens examined: On bark, 08-027070 (LWG); on thorny tree bark, 08-027008/A (LWG).

Usnea lucea Mot. (Fig. 9): Thallus erect, caespitose, up to 5 $\mathrm{cm}$ tall, rigid, yellowish to reddish brown, shiny, papillate, branching subdichotomous to sympodial, main branches constricted and articulate at base, lateral branch-lets dense, short, pseudocyphellate, cortex double layered, central axis solid, colourless. Apothecia terminal, up to $8 \mathrm{~mm}$ in diam., margin and receptacle ciliate. Chemistry: Medulla P+ yellowish, stictic acids present. Earlier this species was known from Tamil Nadu [20]. Specimens examined: On thorny tree bark, 08-027014 (LWG).
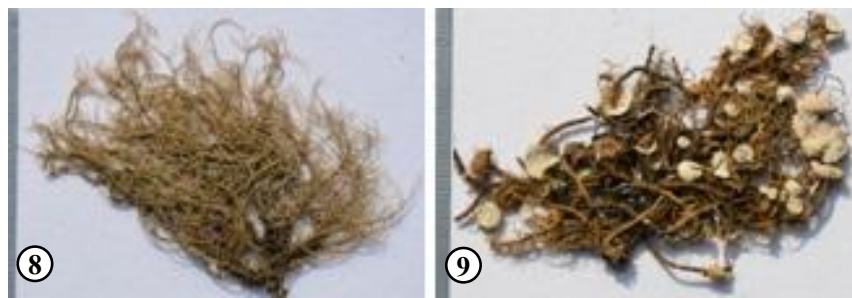

Figure 8: Usnea eumitrioides 9. Usnea lucea

Usnea luridorufa Stirt. (Fig. 10): Thallus erect, caespitose, up to 4-5 cm tall, yellowish brown to darker brown, branching dichotomous to sympodial, main branches nonarticulate and non-inflated, lateral branch - lets very dense, lacking papillae, pseudocyphellae, isidia and soredia, cortex single layered, central axis solid, yellowish. Apothecia 


\section{International Journal of Science and Research (IJSR) \\ ISSN (Online): 2319-7064}

Index Copernicus Value (2013): 6.14 | Impact Factor (2014): 5.611

absent. Chemistry: Medulla $\mathrm{K}+$ yellow then red, $\mathrm{P}+$ deep yellow to red; norstictic, salazinic and stictic acids present. Earlier this species was known from Himalaya (no precise locality), Kerala, Sikkim and Tamil Nadu [20]. Specimens examined: On tree trunk, 08-027062 (LWG).

Usnea spinosula Stirt. (Fig. 11): Thallus erect, up to $3.5 \mathrm{~cm}$ tall, greenish brown to brown, branching subdichotomous to sympodial, main branches nonarticulate, non-inflated, annularly cracked, papillate, lateral branch lets with spinules in tufts, broken and decorticated, central axis solid, colourless. Apothecia terminal, up to $8 \mathrm{~mm}$ in diam., margin ciliate. Chemistry: Medulla $\mathrm{K}+$ yellow then red, $\mathrm{P}+$ yellow, stictic acid complex present. It is an endemic species to India, earlier recorded from Kerala and Tamil Nadu [20]. Specimens examined: On bark, 08-027061 (LWG); on wild rose tree trunk, 08-027015 (LWG).

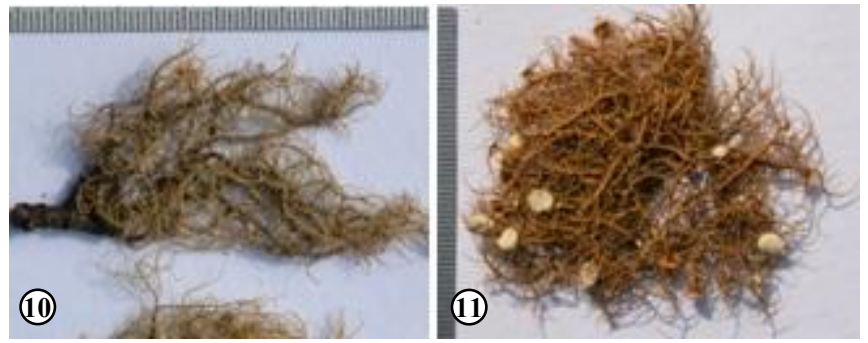

Figure 10: Usnea luridorufa, 11. U. spinosula

\section{Conclusion}

The lichens are sensitive to air pollution and climate change and therefore they are called as bioindicators. The fruticose lichens are more sensitive in comparison to foliose forms and crustose ones are pollution tolerant [21]. However the luxuriant growth of fruticose lichens in Joram Top clearly indicates this area is still free from air pollution. The present study would be helpful for future biomonitoring studies in the area.

\section{Acknowledgements}

We thank Forest Officials and Defence Organization of Ziro Valley for allowing us to survey the area, Director, CSIRNBRI for providing laboratory facilities and to Mr. Komal K. Ingle for assisting in photography. One of the author (KR) would like to thank Principal, P.G .Government College for Girls, Sector - 42, Chandigarh (U.T.) for her cooperation during study.

\section{References}

[1] T.H. Nash, III, "Introduction", in Lichen Biology. $2^{\text {nd }}$ Edition, T.H. Nash, III (ed.), Cambridge University Press, Cambridge, 2008.

[2] D.K. Upreti, P.K. Divakar, S. Nayaka, "Commercial and ethnic use of lichens in India," Economic Botany, 59(3), pp. 269-273, 2005.

[3] S. Nayaka, D.K. Upreti, R. Khare, "Medicinal lichens of India," in Drugs from Plants, P.C. Trivedi (ed.), Avishkar Publishers Distributors, Jaipur, 2010.
[4] V. Shukla, D.K. Upreti, R. Bajpai, Lichens to Biomonitor the Environment. Springer, New Delhi, 2014.

[5] D.D. Awasthi, A Handbook of Lichens, Bishen Singh Mahendra Pal Singh, Dehra Dun, 2000.

[6] S. Nayaka, "Lichen Diversity in India and its Affinities with other Asian Countries", In Proceedings of the $10^{\text {th }}$ International Mycological Congress (IMC10), pp. $67-$ 68, 2014.

[7] J. Rout, A. Kar, D.K. Upreti, "Lichens of Sessa Orchid Sanctuary West Kameng, Arunachal Pradesh", Phytotaxonomy, 4, pp. 38-40, 2004.

[8] A. Pinokiyo, K.P. Singh, J.S. Singh, "Diversity and distribution of lichens in relation to altitude within a protected biodiversity hot spot, north-east India", Lichenologist, 40(1), pp. 47-62, 2008.

[9] K.P. Singh, A. Pinokiyo, "Four foliicolous lichens new to Indian flora", Geophytology, 33(1-2), pp. 119121, 2004.

[10] R. Khare, H. Rai, D.K. Upreti, U. Dubey, R.K. Gupta, "Occurrence of rare, crustose lichen, Ophioparma ventosa (Ophioparmaceae, lichenized Ascomycota), from alpine regions of Arunachal Pradesh, India", Feddes Repertorium, 121(5-6), pp. 184-188, 2010.

[11] J. Rout, A. Kar, D.K. Upreti, "Traditional remedy for kidney stones from a high altitude lichen: Cladonia rangiferina (L.) Wigg (reindeer moss) of Eastern Himalaya", Ethnobotany, 17, pp. 164-166, 2005.

[12] J. Rout, U. Dubey, D.K. Upreti, "Ethnobotanical utilization of Leptogium denticulatum (a foliose lichen) in Arunachal Pradesh, India", Ethnobotany, 22, pp. 136-137, 2010.

[13] K.P. Singh, Singh, P, “A new species of Pyrgillus from India", Lichenologist, 44(6), pp. 773-776, 2012.

[14] K.P. Singh, P. Singh, "Genus Pyrgillus Nyl. (lichenized Ascomycota: Pyrenulaceae) in India", Taiwania, 57(4), pp. 391-395, 2012.

[15] P. Singh, K.P. Singh, A.B. Bhatt, "New species and new records of Thelotremoid Graphidaceae (Lichenized Ascomycota) from Arunachal Pradesh (India)", Taiwania, 58(4), pp. 246-250, 2013.

[16] D.D. Awasthi, A Compendium of the Macrolichens from India, Nepal and Sri Lanka, Bishen Singh Mahendra Pal Singh, Dehra Dun, 2007.

[17] F.J. White, P.W. James, "A New Guide to Microchemical Techniques for the Identification of Lichen Substances", Bull. Br. Lichen Soc., 57(Suppl.), pp. 1-41, 1985.

[18] H.T. Lumbsch, S.M. Huhndorf, "Outline of Ascomycota-2007”, Myconet, 13, pp. 1-58, 2007.

[19] H. Rai, R. Khare, D.K. Upreti, T. Ahti, "Terricolous lichens of India: Taxonomic keys and description," in Terricolous lichens in India Vol. 2. Morphotaxonomic Studies, H. Rai and D.K. Upreiti (eds.), Springer, New Delhi, 2014.

[20] K.P. Singh, G.P. Sinha, Indian Lichens: An Annotated Checklist, Botanical Survey of India, Ministry of Environment and Forests, Salt Lake City, Kolkata, 2010.

[21] I.T. Savillo, "Pyxine cocoes Nyl., a Foliose Lichen as a Potential Bioindicator / Biomoinitor of Air Pollution in 


\section{International Journal of Science and Research (IJSR) \\ ISSN (Online): 2319-7064}

Index Copernicus Value (2013): 6.14 $\mid$ Impact Factor (2014): 5.611

Philippines: An Update”, Enviro News, 16(1), pp. 8, 2010 .

\section{Author Profile}

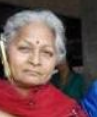

Dr. Kiran Rana is Associate Professor at PG Government College for Girls, Sector - 42, Chandigarh (U. T.). She obtained her Ph.D. degree from Panjab University from Department of Botany.

Dr. Sanjeeva Nayaka is Principal Scientist at CSIRNBRI, Luckow. He received his Ph.D. from Dr. RML Awadh University, Faizabad. He has over 15 years of experience in Lichenology. He has discovered 25 new species of lichens, published more than 100 research papers in peer reviewed journals and 2 books. He visited Antarctica for lichen study.

Ms. Preeti Shukla is a Research Scholar at CSIRNBRI, Lucknow. She has recently submitted her Ph.D. thesis on lichen genus Usnea from Uttarkhand.

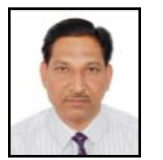

Dr. D.K. Upreti is Chief Scientist at CSIR-NBRI, Lucknow. He is pioneer in multidisciplinary research on lichens in India. He has guided $35 \mathrm{Ph} . \mathrm{D}$. students, published around 300 research papers on lichen and 8 books. He has discovered about 100 new species of lichens and reported 200 new records for India. He has widely travelled in India for exploration of lichens. 